\title{
Comparison of the Energy Performance between Flat-plate and Heat Pipe Evacuated Tube Collectors for Solar Water Heating Systems under Mediterranean Climate Conditions
}

\author{
Altin Maraj ${ }^{* 1}$, Andonaq Londo ${ }^{2}$, Coskun Firat ${ }^{3}$, Alemayehu Gebremedhin ${ }^{4}$ \\ ${ }^{1}$ Department of Energy, Polytechnic University of Tirana, Sheshi Nënë Tereza, 1019 Tirana, Albania \\ e-mail: amaraj@fim.edu.al \\ ${ }^{2}$ Department of Energy, Polytechnic University of Tirana, Sheshi Nënë Tereza, 1019 Tirana, Albania \\ e-mail: alondo@ fim.edu.al \\ ${ }^{3}$ Energy Institute, Technical University of Istanbul, Maslak, Sarıyer, 34469 Istanbul, Turkey \\ e-mail: coskun.firat@itu.edu.tr \\ ${ }^{4}$ Department of Manufacturing and Civil Engineering, Norwegian University of Science and Technology, \\ Teknologivegen 22, 2802 Gjøvik, Norway \\ e-mail: alemayehu.gebremedhin@ntnu.no
}

Cite as: Maraj, A., Londo, A., Firat, C., Gebremedhin, A., Comparison of the Energy Performance between Flat-plate and Heat Pipe Evacuated Tube Collectors for Solar Water Heating Systems under Mediterranean Climate Conditions, J. sustain. dev. energy water environ. syst., 7(1), pp 87-100, 2019, DOI: https://doi.org/10.13044/j.sdewes.d6.0228

\begin{abstract}
In this paper, the energy performance of a flat-plate collector and a heat pipe evacuated tube collector exploited for domestic hot water production in the Mediterranean climate is compared. For this purpose, yearly data obtained from two field-trial solar water heating systems are used. The selected systems are with forced circulation and installed near each other. The studied solar collectors are installed on the roof with the same slope angle of $45^{\circ}$ and the surface azimuthal angle of $10^{\circ}$. The installed surface area of the flat-plate solar collector is $4.41 \mathrm{~m}^{2}$, whereas for the heat pipe evacuated tube collector is $1.5 \mathrm{~m}^{2}$. The annual irradiation on solar collector plane was $1,456 \mathrm{kWh} / \mathrm{m}^{2}$ year. Obtained results showed that the annual solar yield for the flat-plate collector was $664 \mathrm{kWh} / \mathrm{m}^{2}$ year, whereas for the heat pipe evacuated tube collector was $885 \mathrm{kWh} / \mathrm{m}^{2}$ year. The annual average collector efficiencies were 0.494 and 0.62 , respectively.
\end{abstract}

\section{KEYWORDS}

Flat-plate collector, Evacuated tube collector, Heat pipe, Useful energy gain, Losses, Collector efficiency.

\section{INTRODUCTION}

Solar thermal applications offer the possibility to reduce the electricity consumption and consequently our dependency on the fossil fuels. These applications may supply hot water, space heating (or combination), space cooling, process heat, and low temperature for swimming pools. They are equipped with solar collectors of different type, according to the criteria related to the required temperature and efficiency. The knowledge and the efforts to improve the system efficiency are mainly related with the collector efficiency

\footnotetext{
${ }^{*}$ Corresponding author
} 
values. For this reason, many researchers have put efforts in evaluating, analysing, and improving the efficiency of different solar collectors utilized in solar thermal applications.

The total collector area in operation for Albania by the end of 2015 was 183,815 m². According to the heat transfer fluid type, they are all water collectors. Based on the collector type, glazed flat plate collectors have an installed area of $A_{\mathrm{FPC}}=181,389 \mathrm{~m}^{2}$, while evacuated tube collectors that of $A_{\mathrm{ETC}}=1,976 \mathrm{~m}^{2}$ [1]. The widespread use of flat plate collectors in the country is related to their lower costs, compared to the evacuated tube collectors.

Solar collectors are considered a particular kind of heat exchanger, which transform the solar radiant energy into heat. In literature, there are numerous studies on the evaluation of thermal performance for flat-plate and evacuated tube collectors. Some published works and their principal results are summarized below.

Ayompe and Duffy [2] carried out the energy performance analysis of a solar water heating system with flat-plate collectors in a temperate climate (Dublin, Ireland). The author defined the daily performance based on three representative days: overcast, clear sky and intermittent cloud covered. They concluded that for the temperate climate the annual average collector efficiency was $45.6 \%$.

Bhowmik and Amin [3] conducted experiments on two different flat plate collectors. The first one was a standard flat plate collector, while the second one was equipped with a reflective surface. Referring to the standard flat plate collector, they achieved a daily value of the collector efficiency of $51 \%$.

Dang and Sharma [4] investigated the collector performance and optimum tilt as functions of several factors. They confirmed that for year round operation, the maximum solar collected energy from the flat plate collector occurs when the tilt is 0.9 times the latitude angle. Also, the increase in off-south angle is accompanied by the decrease of the yearly effectiveness.

Said et al. [5] enhanced the performance of a flat plate solar collector by using $\mathrm{TiO}_{2}$-nanofluid and PEG 400 dispersant under climate conditions of Kuala Lumpur, Malaysia. In the case of water as heat transfer fluid, the highest efficiency was $42.1 \%$, while for the new fluid it was $76.6 \%$ for $0.3 \%$ vol of Titanium dioxide $\left(\mathrm{TiO}_{2}\right)$.

Wei et al. [6] improved the structure of a flat-plate solar collector by using one large integrated wickless heat pipe instead of side-by-side separated heat pipes. They evaluated the thermal performance of the collector, the theoretical analysis on the energy balance for each component of the collector and developed a transient heat transfer model. The maximum achieved value of the thermal efficiency of the collector was $66 \%$.

Amer et al. [7] developed a transient test method to characterize the dynamic behavior of flat-plate solar collectors. The method was validated by testing a flat-plate collector with aperture area of $2.11 \mathrm{~m}^{2}$. The rate of useful heat gain per unit collector area was predicted using average values of the collector parameters. Also, this quantity was calculated based on measurement data. Predicted and measured values of the useful heat gain per unit collector area indicated a reasonably good agreement between them.

Alvarez et al. [8] investigated experimentally and numerically a newly designed flat-plate collector characterized by its corrugated channel and by the higher surface area $(14 \%)$ in contact with the heat transfer fluid. The study revealed that the efficiency of the flat-plate collector of fin-and-tube type obtained analytically and by the finite element method was 0.439568 and 0.43884 , respectively. Also, the comparison between experimental and numerical results was performed.

Tian et al. [9] performed separate studies of the annual thermal performance of flat plate solar collector and parabolic trough collector fields of a Taars solar heating plant, Denmark. Under the local conditions where the measured annual global radiation was 
$980 \mathrm{kWh} / \mathrm{m}^{2}$ year, the annual specific useful energy gain for the flat plate collectors was $510 \mathrm{kWh} / \mathrm{m}^{2}$ year.

Ayompe and Duffy [10] analyzed the energy performance of a forced solar water heating system equipped with a heat pipe evacuated tube collector area of $3 \mathrm{~m}^{2}$. The work considered a case study in a temperate climate (Dublin, Ireland). From the calculations it was noticed that the energy collected by the heat pipe evacuated collector varied between 6.1 MJ/day (December) and 34.2 MJ/day (June). Whereas, the collector efficiency varied between $47.2 \%$ (December) and 71.4\% (May). The annual values of global insolation on the collector's surface, energy collected by the heat pipe evacuated collector and collector efficiency were respectively 11,760.3 MJ/year, 7,435.1 MJ/year, and 63.0\%.

Redpath [11] investigated the performance of two configurations for thermosiphon heat pipe evacuated tube solar water heaters for the northern maritime climate. The area for each of the two considered solar collectors was $2 \mathrm{~m}^{2}$. The annual total solar irradiation for the south surface orientation and inclined at $45^{\circ}$ was $1,086 \mathrm{kWh} / \mathrm{m}^{2}$ while the mean ambient air was $8.8^{\circ} \mathrm{C}$. The study revealed that internal heat pipe condensers are more effective than external ones. From the calculations, it was noticed that the annual useful energy output for solar water heaters was $1,357 \mathrm{kWh}$ and $1,111 \mathrm{kWh}$, respectively. The study highlighted that the efficiency for the system with internal heat pipe condenser was $63 \%$, while for the other configuration with external heat pipe condenser was $47.4 \%$.

Hazami et al. [12] validated the TRNSYS model of a forced solar water heating system equipped with a heat pipe evacuated tube collector area of $3.4 \mathrm{~m}^{2}$ in a region with typical North-African climate conditions (Borj Cedria, Tunisia). They predicted the long-term performance of the system. From the simulation it was noticed that the collected energy by the heat pipe evacuated collector varied between $300.6 \mathrm{MJ} / \mathrm{m}^{2}$ (January) and $444.7 \mathrm{MJ} / \mathrm{m}^{2}$ (July). The annual values of global insolation on the collector's surface and collected energy by the heat pipe evacuated collector were respectively $5,489.3 \mathrm{MJ} / \mathrm{m}^{2}$ and $4,653.13 \mathrm{MJ} / \mathrm{m}^{2}$. Later, the model was exploited to compare the long-term performances of solar water heating systems equipped with heat pipe evacuated tube collector and flat plate collector $\left(4 \mathrm{~m}^{2}\right)$. The collected energy from the system equipped with the heat pipe evacuated tube collector was $9 \%$ greater than that with flat plate collector where the system efficiencies were $76 \%$ and $67 \%$, respectively.

Gill et al. [13] studied a heat pipe evacuated tube collector installed in an active system under northern maritime climate conditions (Dublin, Ireland). The annual efficiency of the considered collector was $82 \%$. Also, efficiency values were higher in winter months.

Hassanien et al. [14] investigated the performance and the viability of using an evacuated tube solar collector to assist a heat pump for greenhouse heating in Kunming, China. The authors noticed that the average thermal efficiency of the evacuated tube collector ranged between $0.4-0.5$ on sunny periods and $0.35-0.4$ on cloudy periods. The annual thermal efficiency of the solar collector was 0.49 .

Daghigh and Shafieian [15] evaluated theoretically and experimentally the performance of a solar water heating system with evacuated tube heat pipe collector. They presented graphically the daily collector energy intake and the effect of solar radiation. Also, the effect of environmental and functional conditions on thermal efficiency was explained.

Chow et al. [16] carried out experimental and numerical evaluation of the performance for two common types of evacuated tube solar water heaters employed in domestic applications under climate conditions of Hong Kong. Both were thermosiphon systems, where the first solar collector was with single-phase and the second was with two-phase. It was noticed that the annual thermal performance of the two-phase solar water heater was higher than the first one. Also, from the simulations resulted that the 
annual heat obtained was 5,639 MJ/year, 4,996 MJ/year, 4,500 MJ/year for two-phase evacuated tube, single-phase evacuated tube and flat plate collector, respectively.

Sabiha et al. [17] enhanced the performance of a heat pipe evacuated tube collector by using Single Walled Carbon Nanotubes (SWCNT) nanoparticles under climate conditions of Kuala Lumpur, Malaysia. In the case of water as heat transfer fluid, the highest efficiency was $54.37 \%$, while for the new fluid it was $93.43 \%$ for the same flow rate of $0.025 \mathrm{~kg} / \mathrm{s}$.

Ayompe et al. [18] compared the field performance between a flat plate collector $\left(4 \mathrm{~m}^{2}\right)$ and a heat pipe evacuated tube collector $\left(3 \mathrm{~m}^{2}\right)$. The considered forced solar water heating systems were installed in a temperate climate (Dublin, Ireland). The authors calculated the useful energy collected by the solar collectors, collector efficiency, etc. The annual value of global insolation on the collector's surface was $1,087 \mathrm{kWh} / \mathrm{m}^{2}$. Over a year, a unit area of the flat plate collector and the heat pipe evacuated collector each generated $496 \mathrm{kWh} / \mathrm{m}^{2}$ and $681 \mathrm{kWh} / \mathrm{m}^{2}$ of heat respectively. Also, the annual average collector efficiency was $46.1 \%$ and $60.7 \%$ for the flat plate collector and the evacuated tube collector respectively.

Sakhrieh and Al-Ghandoor [19] investigated experimentally the performance of five types of solar collectors under the climate conditions of Al-Zarqa, Jordan. The first four were flat plate (black coated selective copper, blue coated selective, copper collector and aluminum collector), while the last was evacuated tube collector. The average efficiency achieved for the evacuated tube collector was 0.76, while for the flat plate, it varied between 0.57 and 0.62 .

Zambolin and Del Col [20] compared experimentally the thermal performance between a flat plate collector and an evacuated tube collector with direct flow in Padova, Italy. The last was equipped with external compound parabolic concentrator reflectors. Efficiency in steady-state and quasi-dynamic conditions was measured following the standard EN 12975-2 and was compared with measured values. The finding in this work indicated that the efficiency of the flat plate collector was higher when the reduced temperature difference was lower than $0.037 \mathrm{~m}^{2} \mathrm{~K} / \mathrm{W}$ (steady-state and quasi-dynamic conditions) and $0.027 \mathrm{~m}^{2} \mathrm{~K} / \mathrm{W}$ (daily measurements). For bigger values of the reduced temperature difference the flat plate collector efficiency is penalized by the higher heat loss coefficient. From the comparison, the authors noticed a good fit between the values obtained from measurements and quasi-dynamic conditions. In this case, evacuated tube collectors display a similar trend during the entire day, whereas the efficiency of flat plate collectors is lower in the morning and evening hours. Also, the study revealed that the output energy of flat plate collectors overcomes the one of evacuated tube collectors when the inlet temperature is low.

Kalogirou [21] presented optical, thermal and thermodynamic analysis of collectors. Also, a description of methods used to evaluate the collector performance was offered.

In this study, the energy evaluation of flat-plate and heat pipe evacuated tube collectors is performed for Mediterranean climate conditions during a 12-month period. In general, many studies were focused mainly on their evaluation based on Testing Methods leaning on different standards. Long-time performance of the considered solar collectors and their comparison has been rarely examined in the literature. In this research, both collector types were installed in forced circulation systems placed side by side and situated in a region with typical Mediterranean climate conditions of "Cs" group, although there are several researches performed for an annual period in northern maritime, temperate climate, and typical North-African climate.

Also, in this study are shown monthly and annual values of specific useful energy gain and specific losses for both collectors.

The energy evaluation of the considered collectors is performed leaning on the mathematical model provided from the literature. 


\section{DESCRIPTION OF THE SYSTEMS}

The collectors utilized in this work are shown in Figure 1. It shows the external part of the two solar water heating systems, which are installed in the premises of the Department of Energy, Faculty of Mechanical Engineering, Polytechnic University of Tirana - Albania. Tirana is the capital of Albania and is situated in the central part of the country. The average altitude of the city is $110 \mathrm{~m}$ above the sea level and the geographical coordinates are $41.33^{\circ} \mathrm{N}$ and $19.82^{\circ} \mathrm{E}$. The selected town has a typical Mediterranean climate and it falls at "Cs" group according to Köppen climate classification. It is characterized as hot and dry summers and mild and rainy winters [22]. Annual average number of sunny hours is $\bar{n}_{\mathrm{v}}=2,500 \mathrm{~h} /$ year [23].

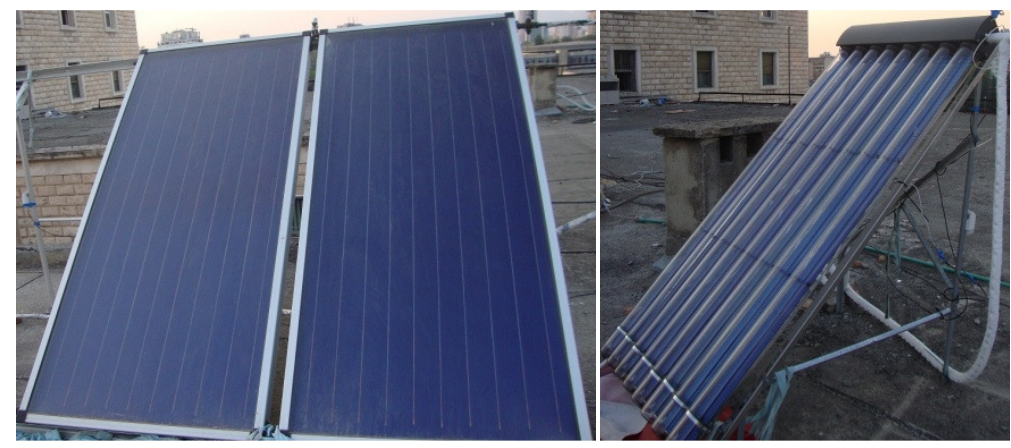

Figure 1. View of the utilized solar collectors

Flat-plate solar collectors used in this work are of selective type and were produced by Isofoton (Spain). A liquid heating flat-plate solar collector consists of the solar energy-absorbing surface, header and riser pipes, transparent cover, and the back insulation. The flux of incident radiation heats the absorbing surface and transfers it to a heat transfer fluid [24].

The evacuated tube collector is with heat pipe and was produced by Augusta Solar $\mathrm{GmbH}$ (Germany). A heat pipe evacuated tube collector consists of a heat pipe inside the vacuum sealed tube, containing a temperature sensitive medium. There are condensation and evaporation sections in the heat pipe. Solar radiation heats up and vaporizes the heat pipe fluid in the evaporation section, and the vapour then rises to the condenser where the vapour emits the heat and is condensed back. The heat transfer fluid flowing through a manifold absorbs the emitted heat. The condensed fluid flows back to the bottom of the heat pipe where the solar radiation begins heating it up again. To work properly, the heat pipes must have a minimum tilt angle in order for vapour to rise and the fluid to flow back [25].

In Table 1 the main technical specifications of the utilized solar collectors are shown.

Table 1. Main technical specifications of the solar thermal collectors

\begin{tabular}{ccc}
\hline & Flat-plate collector [24] & Evacuated tube collector [25] \\
\hline Gross area $\left[\mathrm{m}^{2}\right]$ & 2.4 & 2.1 \\
Aperture area $\left[\mathrm{m}^{2}\right]$ & 2.205 & 1.476 \\
Zero-loss efficiency [-] & 0.773 & 0.735 \\
First-order coefficient $\left[\mathrm{W} / \mathrm{m}^{2} \mathrm{~K}\right]$ & 3.243 & 1.16 \\
Second-order coefficient $\left[\mathrm{W} / \mathrm{m}^{2} \mathrm{~K}^{2}\right]$ & 0.014 & 0.0053 \\
\hline
\end{tabular}

\section{Solar Water Heating system with flat-plate collectors}

One of the Solar Water Heating (SWH) systems utilized in this work was the one with forced circulation. Its main components and the sensor configuration are shown in 
Figure 2. The system was equipped with two selective solar flat-plate collectors connected in parallel. The collector slope was $45^{\circ}$ and the surface azimuthal angle was $-10^{\circ}$.

A mixture of water and propylene glycol in $40 \%$ concentration was used as the heat transfer fluid. This mixture prevents problems like freezing of the heat transfer fluid in low temperatures and the corrosion in system components. The circulation of the heat transfer fluid was achieved by a solar pump, which turns on when the appointed temperature difference is $5^{\circ} \mathrm{C}$. The temperature difference was monitored through the controller. Once returned from the solar collectors, the heat transfer fluid enters into the solar storage. Flowing into an internal spiral tube, its heat is transferred to the sanitary water. The measurement of heat transfer fluid temperatures was achieved by using the thermocouples TS, whereas the ambient air temperature by the thermocouple ATS. The measurement of global solar irradiance on the tilted solar collector area was realised using the sensor SRS, which is a CS10 solar cell [26]. The collected data during the daily operation are transferred from the controller to a PC. Later, they were elaborated by the help of appropriate software [27].

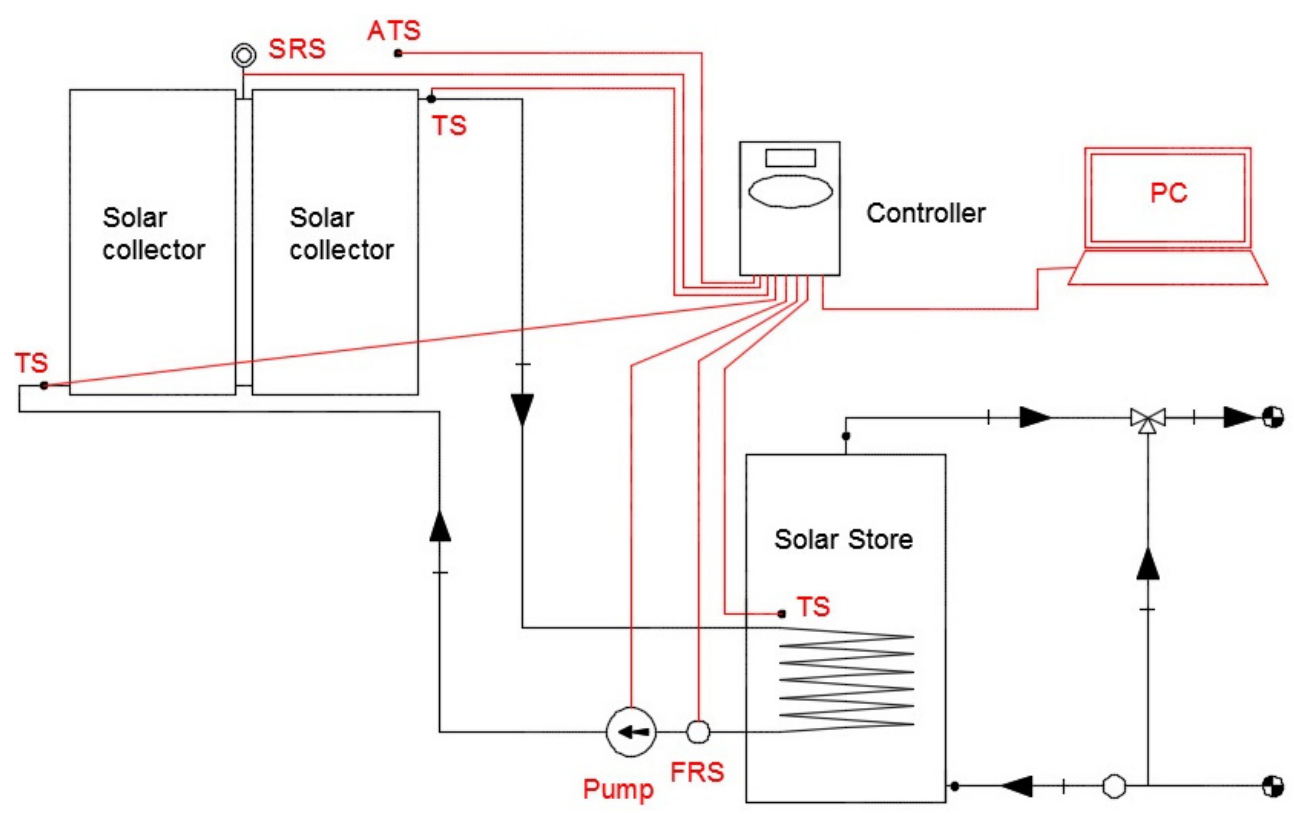

Figure 2. Main components and utilized sensors in the first solar water heating system

\section{The Solar Water Heating system with evacuated tube collector}

One other solar water heating system utilized in this work was with forced circulation also. The operation principle, the layout, and the sensor placement are similar as for the first system described above. The system was equipped with a heat pipe evacuated tube collector. The collector slope was $45^{\circ}$ and the surface azimuthal angle was $-10^{\circ}$. An aqueous solution of higher boiling glycol (antifrogen SOL HT) was used as the heat transfer fluid. This mixture is characterized by a high saturation temperature and low freezing temperature [28].

\section{MATHEMATICAL MODEL}

The solar collector is the most important component of a SWH system. Its main function is to collect the solar irradiation, convert it into heat and further to transfer heat to the working fluid. The First Law of Thermodynamics was followed for the investigation of the energy performance during the considered time period of the two selected types of solar collectors. 
In steady state, the performance of a solar thermal collector is described by an energy balance equation including the incident solar energy $\left(\dot{E}_{\text {sun }}\right)$, optical and thermal losses $\left(\dot{Q}_{\text {loss }}=\dot{Q}_{\text {loss }}^{\text {opt }}+\dot{Q}_{\text {loss }}^{\text {th }}\right)$, and useful energy gain $\left(\dot{Q}_{\mathrm{u}}\right)$. In Figure 3 the energy flows are depicted in the general form.

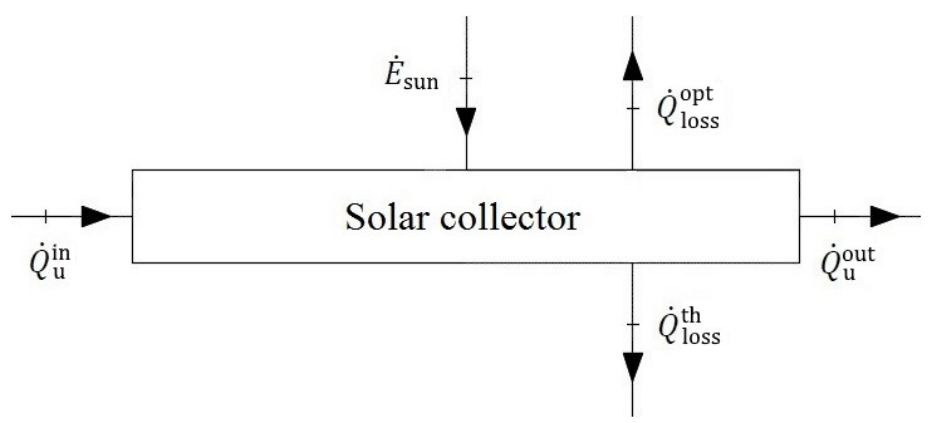

Figure 3. Energy flows for a solar thermal collector

The energy balance equation for a solar thermal collector is given as [29]:

$$
\dot{E}_{\text {sun }}+\dot{Q}_{\mathrm{u}}^{\text {in }}=\dot{Q}_{\mathrm{u}}^{\text {out }}+\dot{Q}_{\text {loss }}
$$

The useful energy gain for a solar thermal collector is defined as [29]:

$$
\dot{Q}_{\mathrm{u}}=\dot{Q}_{\mathrm{u}}^{\text {out }}-\dot{Q}_{\mathrm{u}}^{\text {in }}=\dot{m}_{\mathrm{p}} \times c_{\mathrm{p}} \times\left(T_{\text {out }}-T_{\text {in }}\right)
$$

From eq. (1) we obtained another expression to define the useful energy gain from a solar thermal collector:

$$
\dot{Q}_{\mathrm{u}}=\dot{E}_{\text {sun }}-\dot{Q}_{\text {loss }}
$$

Evaluation of useful energy gain for a solar collector through eq. (3) is a complicated and time-expensive process, since it includes the combined effects of the collector design, the incident solar radiation, the entering fluid conditions, and the ambient air temperature. For these reasons it is more appropriate to utilize eq. (2), because the included parameters can be obtained directly by measurements. Also, eq. (3) can be utilized to define the losses (thermal and optical) from the solar collector $\left(\dot{Q}_{\text {loss }}\right)$.

Collection efficiency is defined as the ratio of the useful energy gain over some specified time period to the incident solar energy over the same period and is given as [29]:

$$
\eta=\frac{\int \dot{Q}_{\mathrm{u}} \times d t}{A_{\mathrm{c}} \times \int G_{\mathrm{t}} \times d t}
$$

This way, the instantaneous efficiency of solar energy conversion to useful thermal energy is given as [29]:

$$
\eta_{i}=\frac{\dot{m} \times C_{\mathrm{p}} \times\left(T_{0}-T_{\mathrm{i}}\right)}{A_{\mathrm{c}} \times G_{\mathrm{t}}}
$$

\section{RESULTS AND DISCUSSIONS}

In this study, the annual energy evaluation and analysis of two different types of solar collectors installed in two solar water heating systems placed side by side in a region with 
typical Mediterranean climate conditions belonging to the "Cs" group were performed. To fulfil these objectives, the database of measured parameters of two solar water heating systems with forced circulation was utilized. Parameters were the tilted global solar irradiance, ambient air temperature, volume flow rate of the heat transfer fluid, and the temperature of the heat transfer fluid in the inlet and the outlet of the considered solar collectors. Then, the energy evaluation was performed by leaning on the mathematical model which refer to the solar collectors. Finally, the obtained results for two selected collectors were compared.

The monthly values of irradiation on solar collector plane are given in Figure 4. For the selected region, the values of this parameter during the summer period were higher when compared to those in the winter period. The magnitude of irradiation values depends mainly from the latitude, season and local climatic conditions. The minimum value of irradiation on solar collector plane for the considered period was recorded in the month of December $H_{\mathrm{T}}^{\min }=69.1 \mathrm{kWh} / \mathrm{m}^{2}$ month, while the maximum was in July with $H_{\mathrm{T}}^{\max }=180.3 \mathrm{kWh} / \mathrm{m}^{2}$ month.

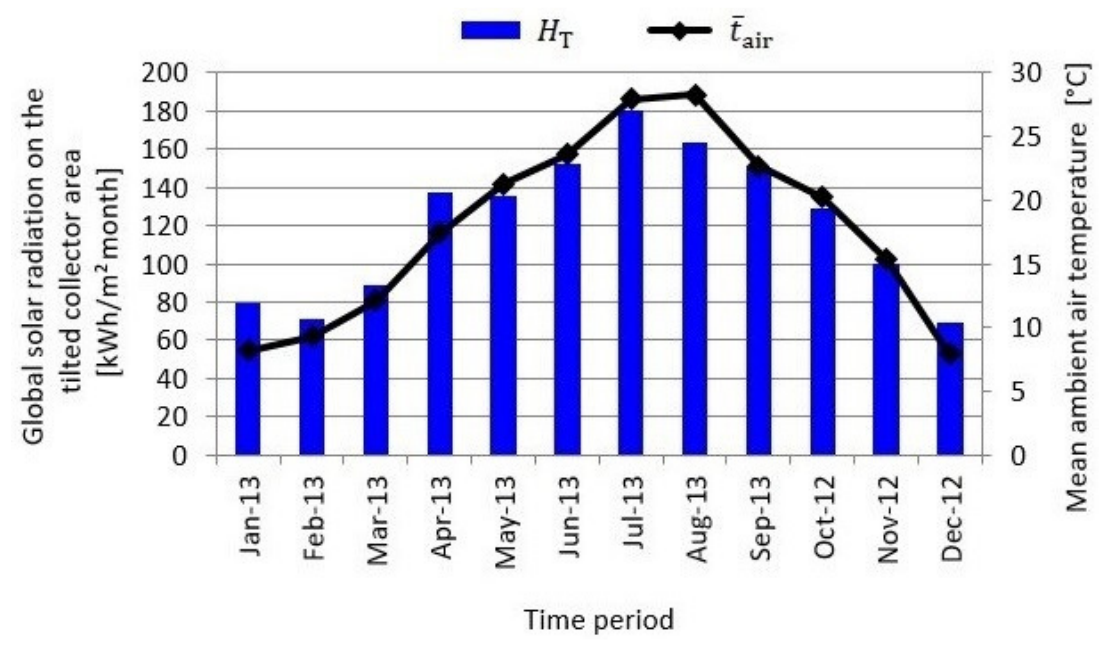

Figure 4. Monthly values of irradiation on solar collector plane and ambient air temperature

Even the mean monthly values of ambient air temperature near the studied solar collectors are shown at Figure 4. It was noticed that ambient air temperature was lower during January and increases gradually towards the summer months. Then, it gradually decreases towards the winter months. Ambient air temperature varied in the interval between $\bar{t}_{\text {air }}=(7.9 \div 28.3){ }^{\circ} \mathrm{C}$, where the minimum value refers to the month of December and the maximum to that of July. Average annual ambient air temperature for the considered period was $\bar{t}_{\mathrm{air}}=17.9{ }^{\circ} \mathrm{C}$.

Keeping in mind that since the areas were different for the two considered solar collectors, then the specific useful energy gain $\left(\dot{q}_{\mathrm{u}}\right)$ was utilized to compare them. In Figure 5 monthly values of specific useful energy gain are shown. Its value was referred to the aperture area of the solar collectors. It was evident that the specific useful energy gain was higher in the months with higher values of insolation than the others. Also, this parameter for evacuated solar tube collector was always higher compared to that of flat-plate collectors. The ratio of these two values were in the range of $q_{\mathrm{u}}^{\mathrm{ETC}}=(1.182 \div 1.513) \times q_{\mathrm{u}}^{\mathrm{FPC}}$. The minimum ratio occurred in April, whereas the maximum in August.

Monthly values of specific losses (optical and thermal) are shown in Figure 6. These values are obtained by the eq. (3). From graphs it was evident that specific losses during the considered time period were lower for the evacuated tube collector in a range of $q_{\text {loss }}^{\text {ETC }}=(0.653 \div 0.806) \times q_{\text {loss }}^{\text {FPC }}$. 


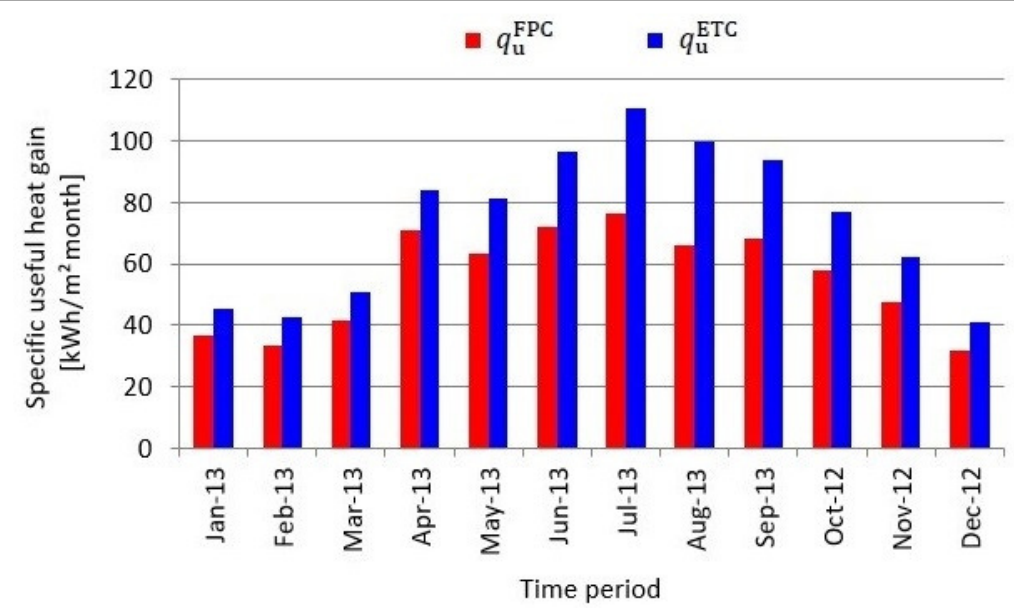

Figure 5. Monthly values of specific useful energy gain for the studied collectors

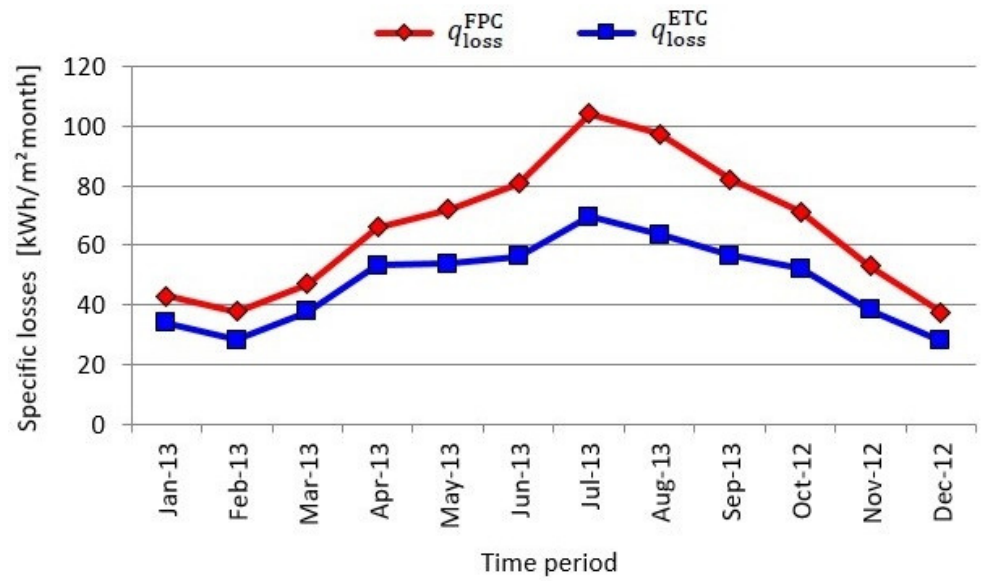

Figure 6. Monthly values of specific losses for the considered solar collectors

In Table 2, the energy balance for the flat-plate collector and the evacuated tube collector are given. They refer to the 12-month time period considered in this study including the irradiation on solar collector plane, useful energy gain, and heat losses from both solar collectors.

Table 2. Energy balances for the studied solar thermal collectors

\begin{tabular}{ccc}
\hline Parameter & Flat-plate collector & $\begin{array}{c}\text { Heat pipe } \\
\text { evacuated tube collector }\end{array}$ \\
\hline $\begin{array}{c}\text { Annual irradiation on solar collector plane } \\
{\left[\mathrm{kWh} / \mathrm{m}^{2} \text { year] }\right.}\end{array}$ & 1,456 & 1,456 \\
$\begin{array}{c}\text { Annual specific useful energy gain } \\
{\left[\mathrm{kWh} / \mathrm{m}^{2} \text { year }\right]}\end{array}$ & 664 & 885 \\
Annual specific losses $\left[\mathrm{kWh} / \mathrm{m}^{2}\right.$ year $]$ & 792 & 571 \\
\hline
\end{tabular}

Monthly values of thermal efficiency for the considered solar collectors are shown at Figure 7.

First, it was noticed that the obtained values of the efficiency for the heat pipe evacuated tube collector were always higher compared to those for the flat-plate collector. The values of the ratio varied between $\eta_{\mathrm{ETC}}=(1.184 \div 1.574) \times \eta_{\mathrm{FPC}}$. The ratio was related to the lower thermal losses which happened during the operation of the evacuated solar tube collector. The minimum ratio between them was noticed during 
November, while the maximum was during August. Also, ratio values were higher during months with high values of insolation, and vice versa.

Second, it was observed that the efficiency values for the heat pipe evacuated solar tube collector were associated with low fluctuations varying between $\eta_{\text {ETC }}=(0.602 \div 0.636)$. These low fluctuations were related with the vacuum presence in this solar collector type, which reduces the unavoidable thermal losses.

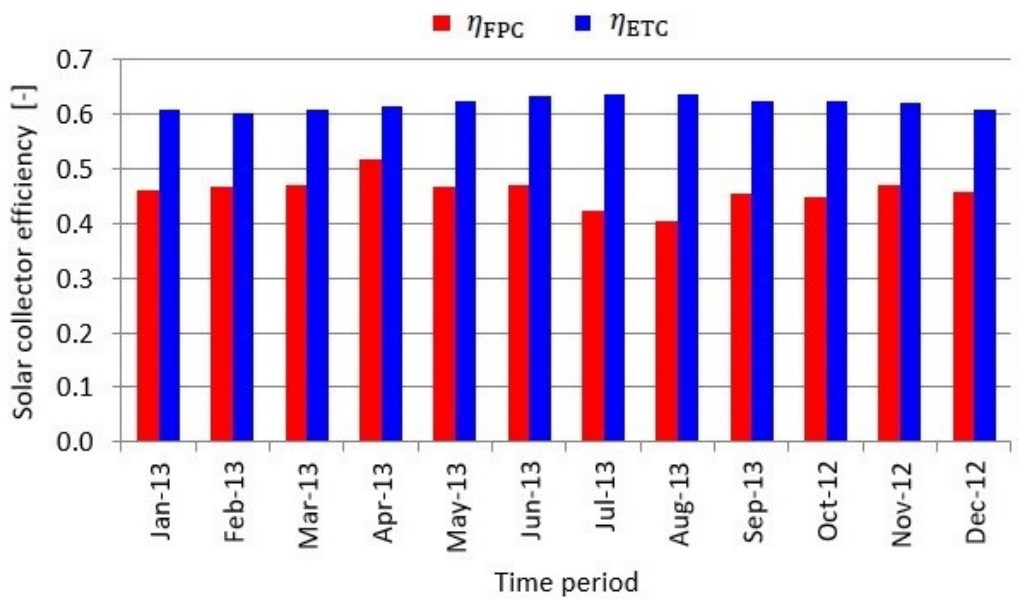

Figure 7. Solar collector efficiency

Third, fluctuations in the efficiency for the flat-plate solar collector were higher compared to those for the heat pipe evacuated solar tube collector. They varied between $\eta_{\text {FPC }}=(0.403 \div 0.518)$, where the lower values were obtained during months with higher values of solar radiation and vice versa. Lower values of thermal efficiency for the flat-plate solar collector were associated with higher thermal losses during these months, wherein the heat transfer fluid temperatures were higher. Whereas, during months with lower values of solar radiation, even the temperature difference between the outlet of the collector and the ambient air was lower. For this reason, during this time period the efficiency of the flat-plate collector was higher.

Based on eq. (1), the annual value of efficiency for the flat-plate solar collector was $\eta_{\text {FPC }}^{\text {annual }}=0.459$, whereas for the heat pipe evacuated solar tube collector it was $\eta_{\text {ETC }}^{\text {annual }}=0.62$. For regions with Mediterranean climate conditions falling at "Cs" group, it can be said that the heat pipe evacuated solar tube collector was nearly $16 \%$ more efficient than the flat-plate collector.

\section{CONCLUSIONS}

The comparison of annual energy performance of a heat pipe evacuated solar tube collector and a flat-plate collector was carried out by exploiting two solar water heating systems with forced circulation installed in a particular region with Mediterranean climate conditions of "Cs" group. To perform, recorded data obtained from these trial installations for a 12-month time period were used. The solar water heating systems were settled as next to each other and operated under the same conditions.

The conclusions were obtained as follows:

- In the selected region, the annual irradiation on solar collector plane for the considered time period was $H_{\mathrm{T}}^{\mathrm{year}}=1,456 \mathrm{kWh} / \mathrm{m}^{2}$ year, whereas the mean annual ambient air temperature was $\bar{t}_{\text {air }}=17.9^{\circ} \mathrm{C}$;

- The specific useful energy gain for evacuated solar tube collector was always higher compared to that of flat-plate collectors fluctuating in the range of $q_{\mathrm{u}}^{\mathrm{ETC}}=(1.182 \div 1.513) \times q_{\mathrm{u}}^{\mathrm{FPC}}$. The annual specific useful energy gain for the 
heat pipe evacuated tube collector was $q_{\mathrm{u}-\mathrm{ETC}}^{\mathrm{year}}=885 \mathrm{kWh} / \mathrm{m}^{2}$ year, whereas for the flat-plate collector was $q_{\mathrm{u}-\mathrm{FPC}}^{\mathrm{year}}=664 \mathrm{kWh} / \mathrm{m}^{2}$ year;

- During the considered time period, the specific losses (optical and thermal) were lower for the evacuated tube collector in a range of $q_{\text {loss }}^{\text {ETC }}=(0.653 \div 0.806) \times$ $q_{\mathrm{u}}^{\mathrm{FPC}}$. Annual specific losses for the heat pipe evacuated tube collector were $q_{\text {loss-ETC }}^{\text {year }}=571 \mathrm{kWh} / \mathrm{m}^{2}$ year, whereas for the flat-plate collector were $q_{\text {loss-FPC }}^{\text {year }}=792 \mathrm{kWh} / \mathrm{m}^{2}$ year;

- The efficiency values for the heat pipe evacuated solar tube collector fluctuated between $\eta_{\mathrm{ETC}}=(0.602 \div 0.636)$, whereas for the flat-plate solar collector they varied between $\eta_{\mathrm{FPC}}=(0.403 \div 0.58)$;

- For the selected region and time period the annual value of efficiency for the flat-plate solar collector was $\eta_{\text {FPC }}^{\text {annual }}=0.459$, whereas for the heat pipe evacuated solar tube collector it was $\eta_{\mathrm{ETC}}^{\text {annual }}=0.62$.

\section{ACKNOWLEDGEMENT}

The authors acknowledge the financial support from the Agency for Research, Technology, and Innovation- Government of Albania through the project "Water and Energy 2010-2012". Utilized solar water heating systems were provided through this project, which included also a doctorate thesis.

\section{NOMENCLATURE}

$A_{\mathrm{c}}$

$A_{\mathrm{ETC}}$

$A_{\mathrm{FPC}}$

$C_{\mathrm{p}}$

$\dot{E}_{\text {sun }}$

$G_{\mathrm{t}}$

$H_{\mathrm{T}}^{\max }$

$H_{\mathrm{T}}^{\min }$

$H_{\mathrm{T}}^{\mathrm{year}}$

$\dot{m}$

$\bar{n}_{\mathrm{v}}$

$\dot{Q}_{\text {loss }}$

$\dot{Q}_{\text {loss }}^{\text {opt }}$

$\dot{Q}_{\text {loss }}^{\text {th }}$

$\dot{Q}_{\mathrm{u}}$

$\dot{Q}_{\mathrm{u}}^{\text {in }}$

$\dot{Q}_{\mathrm{u}}^{\text {out }}$

$\dot{q}_{\mathrm{u}}$

$q_{\mathrm{u}}^{\mathrm{ETC}}$

$q_{\mathrm{u}}^{\mathrm{FPC}}$

$q_{\mathrm{u}-\mathrm{ETC}}^{\text {year }}$

$q_{\mathrm{u}-\mathrm{FPC}}^{\mathrm{year}}$ collector area

area of evacuated tube collector

area of flat-plate collector

fluid specific heat

incident solar energy

total solar irradiance

maximum monthly value of irradiation on solar

collector plane

minimum monthly value of irradiation on solar

collector plane

annual irradiation on solar collector plane

mass flow rate

annual averaged number of sunny hours

losses

optical losses

thermal losses

useful energy gains

energy flow at the collector inlet

energy flow at the collector outlet

specific useful energy gains

specific useful energy gains for the evacuated tube collector

specific useful energy gains for the flat-plate collector annual specific useful energy gains for the evacuated tube collector

annual specific useful energy gains for the flat-plate collector $\left[\mathrm{m}^{2}\right]$

$\left[\mathrm{m}^{2}\right]$

$\left[\mathrm{m}^{2}\right]$

$[\mathrm{kJ} / \mathrm{kgK}]$

[W]

$\left[\mathrm{W} / \mathrm{m}^{2}\right]$

[kWh/m²month]

$\left[\mathrm{kWh} / \mathrm{m}^{2} \mathrm{month}\right]$

$\left[\mathrm{kWh} / \mathrm{m}^{2}\right.$ year $]$

$[\mathrm{kg} / \mathrm{s}]$

[h/year]

[W]

[W]

[W]

[W]

[W]

[W]

$\left[\mathrm{W} / \mathrm{m}^{2}\right]$

[kWh $/ \mathrm{m}^{2}$ month]

[kWh/m $\mathrm{m}^{2}$ month]

$\left[\mathrm{kWh} / \mathrm{m}^{2}\right.$ year]

[kWh/m²year] 


\begin{tabular}{llc}
\hline$q_{\text {loss }}^{\text {ETC }}$ & specific losses for the evacuated tube collector & {$\left[\mathrm{kWh} / \mathrm{m}^{2}\right.$ month $]$} \\
$q_{\text {loss }}^{\text {FPS }}$ & specific losses for the flat-plate collector & {$\left[\mathrm{kWh} / \mathrm{m}^{2}\right.$ month $]$} \\
$q_{\text {loass-ETC }}^{\text {year }}$ & annual specific losses for the evacuated tube collector & {$\left[\mathrm{kWh} / \mathrm{m}^{2}\right.$ year $]$} \\
$q_{\text {loass-FPC }}^{\text {year }}$ & annual specific losses for the flat-plate collector & {$\left[\mathrm{kWh} / \mathrm{m}^{2}\right.$ year $]$} \\
$t$ & time & {$[\mathrm{s}]$} \\
$\bar{t}_{\text {air }}$ & mean ambient air temperature & {$\left[{ }^{\circ} \mathrm{C}\right]$} \\
$T_{0}$ & outlet temperature & {$[\mathrm{K}]$} \\
$T_{\mathrm{i}}$ & inlet temperature & {$[\mathrm{K}]$}
\end{tabular}

\section{Greek letters}

$\eta \quad$ efficiency

$\eta_{\mathrm{i}} \quad$ instantaneous efficiency

$\eta_{\mathrm{ETC}} \quad$ efficiency for the heat pipe evacuated tube collector

$\eta_{\text {FPC }}$ efficiency for the flat-plate collector tube collector annual value of efficiency for the flat-plate solar collector

\section{REFERENCES}

1. Weiss, W., Spörk-Dür, M. and Mauthner, F., Solar Heat Worldwide Global Market Development and Trends 2016 - Detailed Market Figures 2015, IEA-SHCP, 2017, http://www.iea-shc.org/data/sites/1/publications/Solar-Heat-Worldwide-2017.pdf, [Accessed: 11-June-2017]

2. Ayompe, L. M. and Duffy, A., Analysis of the Thermal Performance of a Solar Water heating System with flat Plate Collectors in a Temperate Climate, Applied Thermal Engineering, Vol. 58, Issues 1-2, pp 447-454, 2013, https://doi.org/10.1016/j.applthermaleng.2013.04.062

3. Bhowmik, H. and Amin, R., Efficiency improvement of flat Plate Collector using Reflector, Energy Reports, Vol. 3, pp 119-123, 2017, https://doi.org/10.1016/j.egyr.2017.08.002

4. Dang, A. and Sharma, J. K., Performance of flat Plate Solar Collectors in Off-south orientation in India, Energy Conversion and Management, Vol. 23, No. 3, pp 125-130, 1983, https://doi.org/10.1016/0196-8904(83)90053-5

5. Said, Z., Sabiha, M. A., Saidur, R., Hepbasli, A., Rahim, N. A., Mekhilef, S. and Ward, T. A., Performance enhancement of a flat Plate Collector using Titanium Dioxide Nanofluid and Polyethylene Glycol dispersant, Journal of Cleaner Production, Vol. 92, pp 343-353, 2015, https://doi.org/10.1016/j.jclepro.2015.01.007

6. Wei, L., Yuan, D., Tang, D. and Wu, B., A Study on a Flat-plate type of Solar heat Collector with an integrated heat Pipe, Solar Energy, Vol. 97, pp 19-25, 2013, https://doi.org/10.1016/j.solener.2013.07.025

7. Amer, E. H., Nayak, J. K. and Sharma, G. K., Transient Method for testing Flat-plate Solar Collectors, Energy Conversion and Management, Vol. 39, No. 7, pp 549-558, 1998, https://doi.org/10.1016/S0196-8904(97)10014-0

8. Alvarez, A., Cabeza, O., Muñiz, M. C. and Varela, L. M., Experimental and Numerical investigation of a Flat-plate Solar Collector, Energy, Vol. 35, No. 9, pp 3707-3716, 2010, https://doi.org/10.1016/j.energy.2010.05.016

9. Tian, Z., Perers, B., Furbo, S. and Fan, J., Annual measured and simulated Thermal Performance analysis of a Hybrid Solar district heating Plant with flat Plate Collectors and Parabolic trough Collectors in Series, Applied Energy, Vol. 205, pp 417-427, 2017, https://doi.org/10.1016/j.apenergy.2017.07.139 
10. Ayompe, L. M. and Duffy, A., Thermal Performance analysis of a Solar Water heating System with heat Pipe evacuated Tube Collector using Data from a Field Trial, Solar Energy, Vol. 90, pp 17-28, 2013, https://doi.org/10.1016/j.solener.2013.01.001

11. Redpath, D. A. G., Thermosyphon Heat-pipe evacuated Tube Solar Water Heaters for northern Maritime Climates, Solar Energy, Vol. 86, No. 2, pp 705-715, 2012, https://doi.org/10.1016/j.solener.2011.11.015

12. Hazami, M., Koli, S., Naili, N. and Farhat, A., Long-term Performances prediction of an evacuated Tube Solar Water heating System used for Single-family Households under typical Nord-African Climate, Solar Energy, Vol. 94, pp 283-298, 2013, https://doi.org/10.1016/j.solener.2013.05.020

13. Gill, L., Mac Mahon, J. and Ryan, K., The Performance of an evacuated Tube Solar hot Water System in a Domestic House throughout a Year in a Northern Maritime Climate (Dublin), Solar Energy, Vol. 137, pp 261-272, 2016, https://doi.org/10.1016/j.solener.2016.07.052

14. Hassanien, R., Hassanien, E., Li, M. and Tang, Y., The evacuated Tube Solar Collector assisted heat Pump for heating Greenhouses, Energy and Buildings, Vol. 169, pp 305-318, 2018, https://doi.org/10.1016/j.enbuild.2018.03.072

15. Daghigh, R. and Shafieian, A., Theoretical and Experimental analysis of thermal Performance of a Solar Water heating System with evacuated Tube heat Pipe Collector, Applied Thermal Engineering, Vol. 103, pp 1219-1227, 2016, https://doi.org/10.1016/j.applthermaleng.2016.05.034

16. Chow, T., Dong, Zh., Chan, L., Fong, K. and Bai, Y., Performance evaluation of evacuated Tube Solar Domestic hot Water Systems in Hong Kong, Energy and Buildings, Vol. 43, No. 12, pp 3467-3474, 2011, https://doi.org/10.1016/j.enbuild.2011.09.009

17. Sabiha, M. A., Saidur, R., Hassani, S., Said, Z. and Mekhilef, S., Energy Performance of an evacuated Tube Solar Collector using single walled Carbon Nanotubes Nanofluids, Energy Conversion and Management, Vol. 105, pp 1377-1388, 2015, https://doi.org/10.1016/j.enconman.2015.09.009

18. Ayompe, L. M., Duffy, A., Mc Keever, M., Conlon, M. and Mc Cormack, S. J., Comparative Field Performance Study of Flat-plate and heat Pipe evacuated Tube Collector in a Temperate Climate, Energy, Vol. 36, pp 3370-3378, 2011, https://doi.org/10.1016/j.energy.2011.03.034

19. Sakhrieh, A. and Al-Ghandoor, A., Experimental investigation of the Performance of five Type of Solar Collectors, Energy Conversion and Management, Vol. 65, pp 715-720, 2013, https://doi.org/10.1016/j.enconman.2011.12.038

20. Zambolin, E. and Del Col, D., Experimental analysis of Thermal Performance of flat Plate and evacuated Tube Solar Collectors in stationary Standard and daily conditions, Solar Energy, Vol. 84, No. 8, pp 1382-1396, 2010, https://doi.org/10.1016/j.solener.2010.04.020

21. Kalogirou, S. A., Solar Thermal Collectors and Applications, Progress in Energy and Combustion Science, Vol. 30, No. 3, pp 231-295, 2004, https://doi.org/10.1016/j.pecs.2004.02.001

22. Peel, M. C., Finlayson, B. L. and McMahon, T. A., Updated World Map of the Koppen-Geiger Climate Classification, Hydrology and Earth System Sciences Discussions, Vol. 4, pp 439-473, 2007, https://doi.org/10.5194/hessd-4-439-2007

23. AKBN, Solar Energy, http://www.akbn.gov.al/images/pdf/energji-te -rinovueshme/Energjia_Diellore.pdf, [Accessed: 02-January-2013]

24. Operating and Maintenance Manual: Isotherm Plus Collector, 2010, www.isofoton.com, [Accessed: 04-June-2014]

25. SPF 2015, Solar Collector Factsheet Augusta-solar AS 10 HP8, C1684, http://www.spf.ch/fileadmin/daten/reportInterface/kollektoren/factsheets/scf1684en. pdf, [Accessed: 04-June-2014] 
26. Resol, CS10 Solar Cell, http://www.resol.de/Produktdokumente/ 48005450_CS10.daten.pdf, [Accessed: 04-June-2014]

27. Maraj, A., The Simulation and the Study of Operation for three different Types of Solar Water heating Systems for Climate Conditions of Central Part of Albania, Ph.D. Thesis, Polytechnic University of Tirana, Faculty of Mechancial Engineering, Department of Energy, Tirana, Albania, 2014.

28. Resol,

Heat

Transfer

Fluid, http://www.resol.de/index/produktdetail/kategorie/3/id/36/sprache/en, [Accessed: 04-June-2014]

29. Duffie, J. A. and Beckman, W. A., Solar Engineering of Thermal Processes ( $4^{\text {th }}$ ed.), John Wiley \& Sons, New Jersey, USA, 2013, https://doi.org/10.1002/9781118671603 